\title{
PLANNING CONSERVATION FOR OLD DHAKA - A GUIDELINE FOR PREVENTIVE INTERVENTIONS
}

\author{
Mohammad Sazzad Hossain*
}

\begin{abstract}
Dhaka has been transforming due to adaptation of settlements into its fabric for more than 400 years. The existing fabric can be seen as overlapping layers of successive interventions. Rapid urbanization, shifting economic activities, changes in land use pattern, growing density of new settlements, modern transportation are bringing rapid transformation in the historic fabric. To promote the historic urban structures, characterized by the strong sense of continuity, conservation at urban level has now become an urgent issue. The objectie of the paper is to develop a framework to revatalize the old city through legible and sustainable integration of the historic layers in the existing tissue. The paper attempts to outline a comprehensive guideline for conservation to manage rapid transformation and maintain the historic fabric.
\end{abstract}

Keywords: Physical planning, Conservation, Revitalization.

\section{PREAMBLE}

The old city is currently the commercial nerve of Metropolitan Dhaka, that covers an area of 284.3 acres with a population of $8,87,000$. The area possesses $15 \%$ of the total population of urban Dhaka while occupying only $7 \%$ of its gross builtup area. (DMDP 1995-2015, Vol 11). Most of the area is facing gradual physical deterioration. Scarcity of open spaces, coupled with high plot coverage limited the scope for recreation and cultural activities. The social characteristic of the old district have undergone changes. Historic buildings have been subdivided for multiple families and densities have risen to inordinate level; informal settlements are growing without considering the historic interventions. The paper will make analysis of the historic layers with successive transformation in the fabric and finally outline a strategic approach for conservation.

\section{METHODOLOGY}

The study is carried out as desk-top research including review of literatures, and field survey. Historical Research ${ }^{l}$ method may be included partly to establish the physical growth pattern's chronology and legacy. To mitigate the research problems Qualitative Research $^{2}$ method will be followed. The study will have two measures of approach:

1. The theoretical part will be based on literature survey.

2. Field research will be based on Empirical survey that will have two types of data collection and analysis:

Quantitative data: Involves architectural survey and analysis of numerical data such as land use, infrastructure, on site investigation at small scale etc.

Qualitative data: Involves analysis of data such as interview, history analysis etc.

Documentary research and on-site investigations will be important to identify the historic interventions and urban elements. It will be continuation of author's previous study on the heritage site.

\section{HISTORIC LAYERS}

The old city has following identical layers in its fabric:

* Mohammad Sazzad Hossain, Assistant Professor, Department of Architecture, Southeast University, Dhaka, Bangladesh.

1 Historic Research is a research based on describing the past. This type of research includes for instance, investigations like the recording, analysis and interpretation of events in the past with the purpose of discovering generalizations and deductions that can be useful in understanding the past, present and to a limited extent, can anticipate the future (Landman,1988).

2 Qualitative Research is multi method in focus, involving an interpretive, naturalistic approach to its subject matter. That means qualitative researchers study things in their natural settings, attempting to make sense of, or interpret phenomena in items of the meaning people bring to them. Qualitative research involves the studies use and collection of a variety of empirical materials .Qualitative research is specially effective in obtaining culturally specific information about the values, opinions, behaviors and social context of particular population (Denzin \& Lincoln, 2000). 


\subsection{Pre Mughal Settings (before 1608)}

From about the 9th century A.D. Dhaka was governed by the Sena Kings. During the Sena dynasty Dhakesshwari Temple was built (Taifoor, 1956). After the Sena dynasty, Dhaka was successively ruled by the Turkish and Afghans. Afghan fort was built by Afghan rulers (Dani,1956). Before 1608 AD, Dhaka was a trading centre for pre Mughal capital located at Sonargaon and consisted of few market centers along with few localities of craftsmen and business men. All these localities were confined within the circuit of the old Dholai khal. The tantis (weaver) and the sankharis (shell cutter) are believed to be the oldest inhabitant of the city and they still live in the area. (Dani,1962). In most of the localities, houses of the local craftsmen were accompanied by small factory. The row houses of Shankhari bazaar had narrow frontage of 6 to 10 feet width and 30 to 40 feet depth and were vertically extended up to 4 storied (Taifoor, 1956). Tanti bazaars also had similar type of settlements. The linear organization of houses at both sides along narrow lane resulted very compact settlement pattern (Figures-1,2,3 \& Table-1).

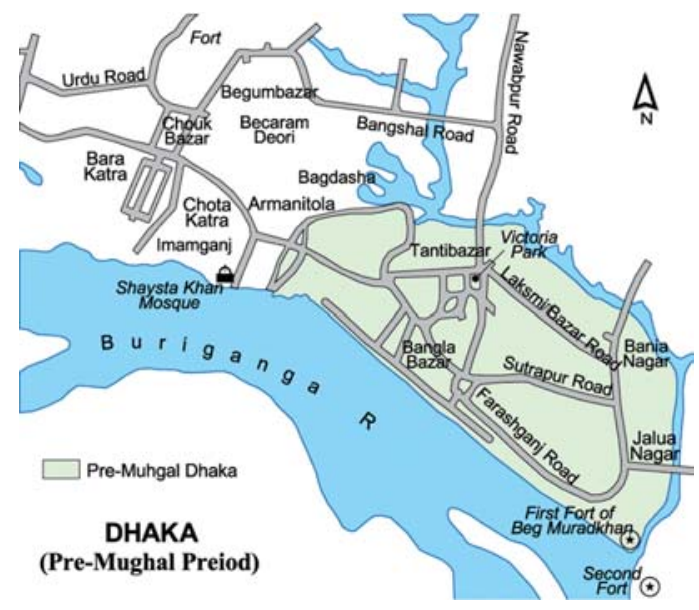

Figure-1: Pre-Mughal Dhaka Source: Islam, 1996b

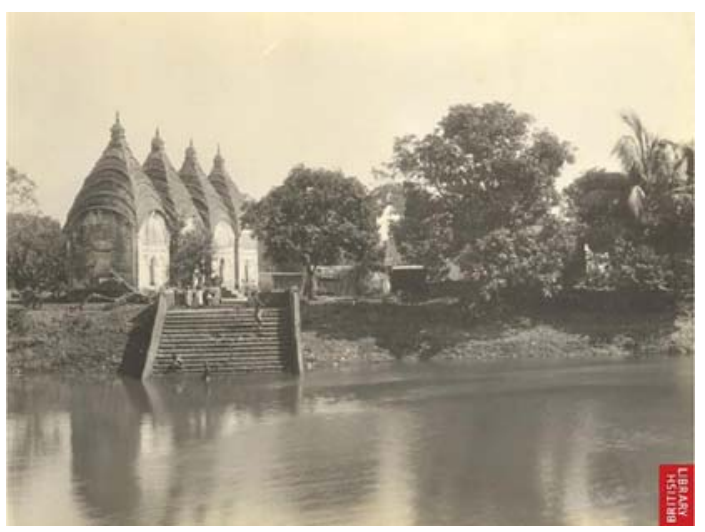

Figure-2: Dhakeshwari mandir in 1904(source British museum)

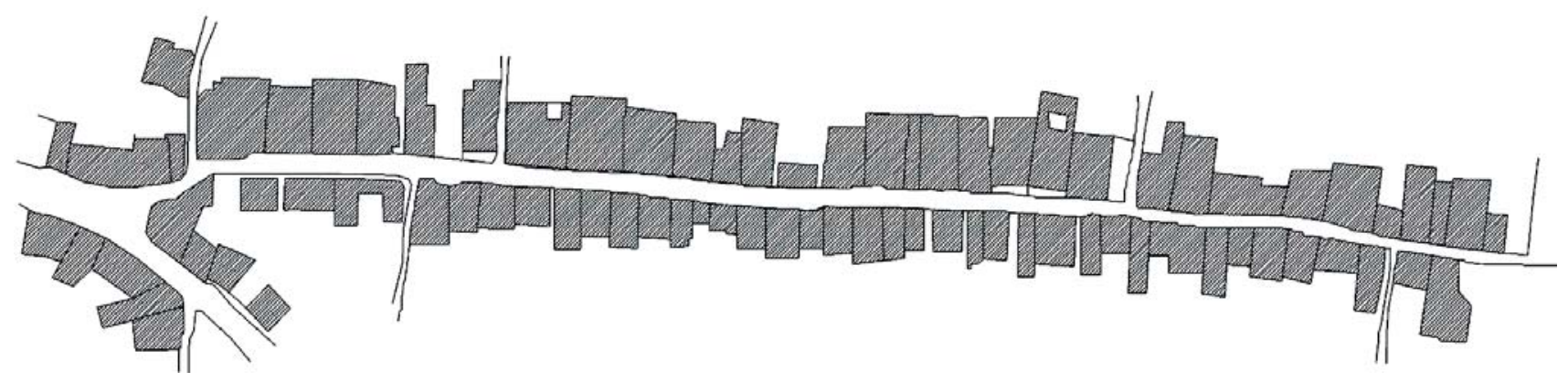

Figure-3: Lay out of Shankhari bazaar in late 18th century. (Ahmed: 2012)

Table-1: Settlement types in Pre-Mughal Dhaka

\begin{tabular}{|l|l|}
\hline \multicolumn{1}{|c|}{ TYPES } & \multicolumn{1}{c|}{ SETTLEMENTS } \\
\hline Market Centers & $\begin{array}{l}\text { Sankhari Bazar (shell cutter's locality) Tanti Bazar (weaver's market), } \\
\text { Laksmi bazaar, Bangla bazaar }\end{array}$ \\
\hline $\begin{array}{l}\text { Localities of crafts man \& } \\
\text { businessman }\end{array}$ & $\begin{array}{l}\text { Kumartoli (potter's locality), Patuatuli (jute-silk painters areas), Sutrapur (carpenter's area), } \\
\text { Bania Nagar (trader's area), Jalua Nagar (fisherman's locality), Bania Nagar and Goal Nagar. }\end{array}$ \\
\hline Fort & Old Afghan Fort \\
\hline Religious & Dhakeshwari Temple, Jaykali Temple \& Lukshminarayan Temple, Binat Bibi Mosque \\
\hline
\end{tabular}




\subsection{Mughal Settings(1608-1764)}

The Mughal rulers established the city as the capital of Bengal to control the trade and commerce in the entire region. It started to extend westward up to Sarai begampur and northward to Bagh-I- badshahi. Under Shaista Khan (1662-1679), the city then stretched for $20 \mathrm{~km}$ in length and $12 \mathrm{~km}$ in breadth and contained nearly a million people (Ahmed, 1986). (Figures-4,5,6 \& Table-2)

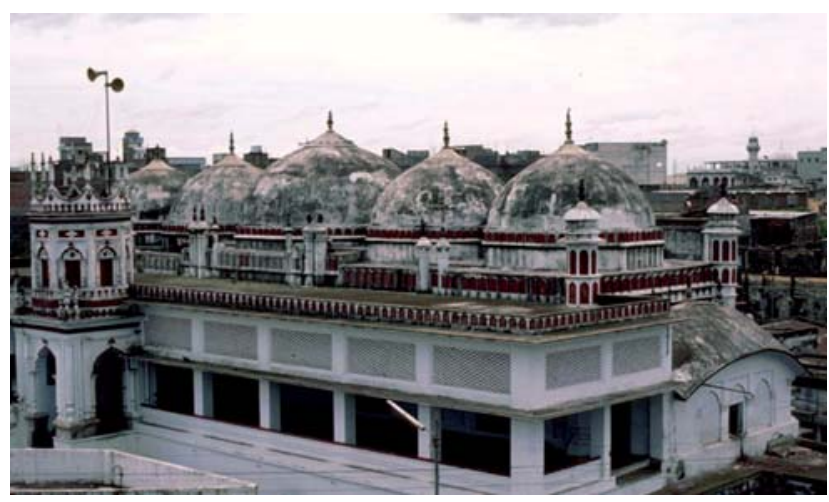

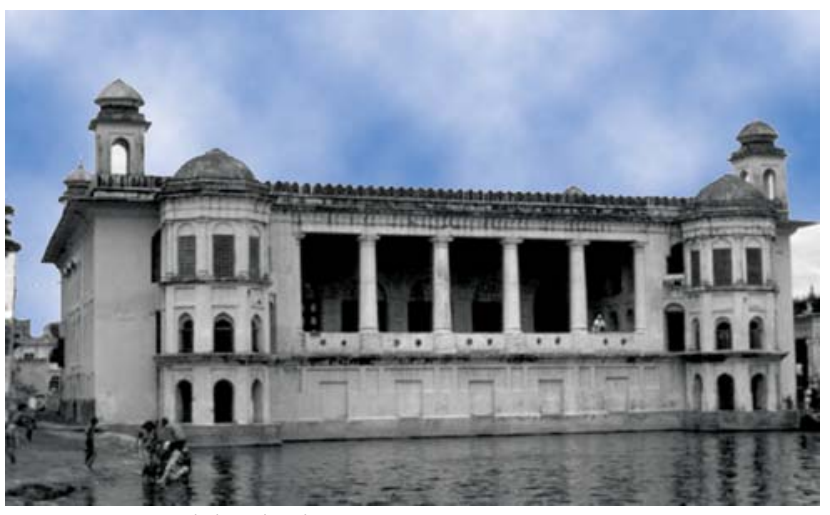

Figure-4: Hussaini Dalan in 1982 source: Aga Khan Visual Archive, MIT

Figure-5: Kartalab Khan Mosque in 1982 source: Aga Khan Visual Archive, MIT

Table-2: Types of Mughal monuments in old Dhaka

\begin{tabular}{|l|l|}
\hline \multicolumn{1}{|c|}{ TYPES } & \multicolumn{1}{c|}{ MONUMENTS } \\
\hline $\begin{array}{l}\text { Mosques and other religious } \\
\text { buildings }\end{array}$ & $\begin{array}{l}\text { Khan Mohammad Mirdha Mosque, Kartalab Khan's Mosque, Star Mosque, Chauk Bazaar } \\
\text { Mosque, Farrukhsiyar Mosque, Begum Bazaar Mosque, Hussaini Dalan }\end{array}$ \\
\hline Tombs & Tomb of Bibi Pari, Bibi Champa \\
\hline Caravan Sari & Bara Katra \& Choto Katra \\
\hline Fortress \& Palace & Incomplete Fortress at Lal Bagh \\
\hline
\end{tabular}

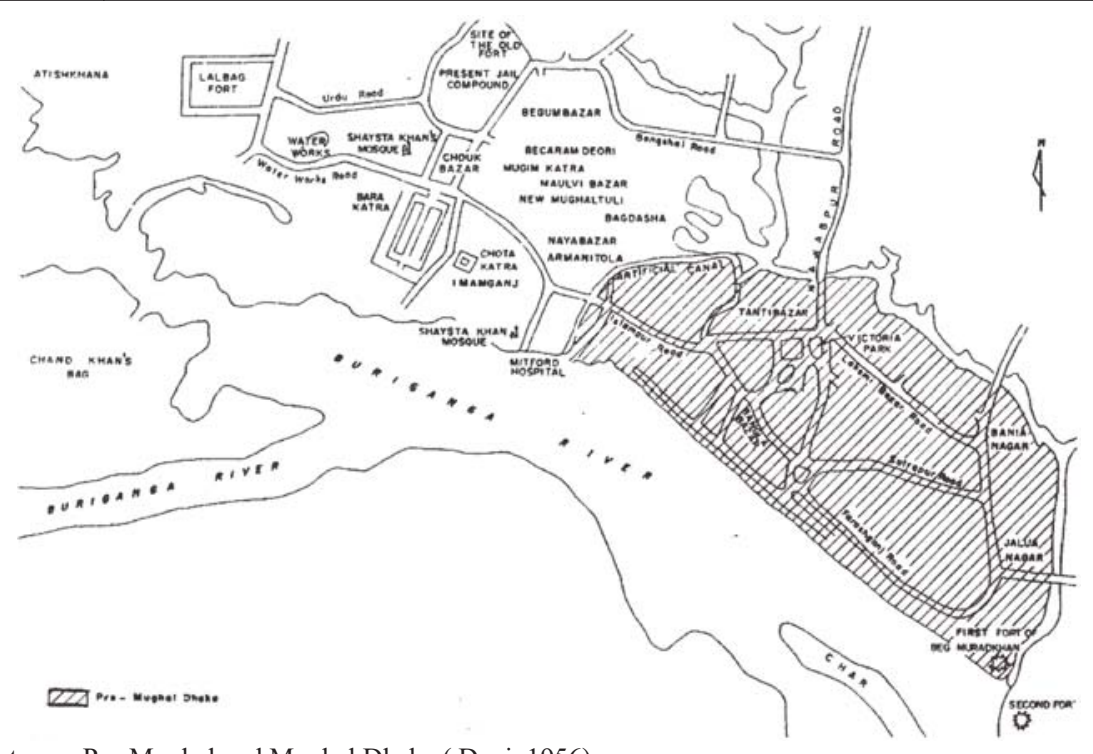

Figure-6: Demarcation between Pre-Mughal and Mughal Dhaka (Dani, 1956). 
The local roads were pedestrian and the river and canals were the important traffic conduit of the city. In Mughal Dhaka there were several bridges that are completely lost now. The city was divided into a number of neighborhoods which was a cluster of houses webbed with intricate narrow lanes (Islam, 1996a). The narrow lanes were paved with bricks in 1677-79 (Dani, 1962). There were two principal roads: one running parallel to the river from Victoria Park to the western fringe of the city and the other ran from the Park to Tejgaon. The intersections of the narrow lanes formed wider and irregular nodes that acted as civic space at local level. The sense of enclosure of these spaces was very intimate in scale. Some of the local nodes turned into 'chowks' (squares) of mohallahs (neighborhood), others were rather intimate in nature and held local social gathering (Nilufar, 2011). Dhaka lacked any kind of corporate or municipal institutions during the Mughal period (Gupta, 1989). The functional zoning of the Mughal Dhaka was as follows:

\subsubsection{Zone-1 (Residential zone):} (See Table-3)

\subsubsection{Zone-2 (Service zone):}

The cottage industries and trading areas of pre Mughal period and some other localities used to house the major part of the city's low class population consisting of artisans, laborers and traders. These pre Mughal localities, confined within the circuit of the old Dholai khal (a cannal), were the service zone of Mughal city. Those localities were almost segregated from the high-class residential areas.

\subsubsection{Zone-3 (CBD):}

During Mughal period Chauk Bazaar was developed as the main business center near Bara-Katra. The market was well located to serve both the upper class and the lower class residential areas. Chauk Bazaar was connected with the Sadarghat (a landing platform at the bank of Buriganga River) by a road running parallel to the river. Another commercial centre was located at Bangla Bazaar and that was the main shopping centre before the Mughals (Taifoor, 1956) (Figures-7, 8 \& Table-4).

Table-3: Types of Mughal residential buildings in old Dhaka

\begin{tabular}{|l|l|}
\hline \multicolumn{1}{|c|}{ USER GROUP } & \multicolumn{1}{|c|}{ RESIDENTIAL AREAS } \\
\hline $\begin{array}{l}\text { Though it was an incomplete fort but it indicates the } \\
\text { Mughal intention to establish the residence of the prince } \\
\text { at Lal Bagh fort }\end{array}$ & Lal Bagh Fort \\
\hline $\begin{array}{l}\text { Rich but comparatively ordinary citizens who often could } \\
\text { be identified with the Mughal nobilities. }\end{array}$ & $\begin{array}{l}\text { Large palatial buildings at Becharam Dewri, Aga Sadeq Dewri, } \\
\text { Ali Naqi Dewri and Amanat Khan Dewri. }\end{array}$ \\
\hline The princes and wealthy elites & Residential buildings along the riverfront \\
\hline
\end{tabular}

Table-4: Types of building in the CBD of Mughal Dhaka.

\begin{tabular}{|l|l|}
\hline \multicolumn{1}{|c|}{ TYPES } & \multicolumn{1}{c|}{ BUILDINGS } \\
\hline Trade Center & Chauk \& Bangla Bazaar \\
\hline Caravan Sarai & Bara Katra \& Chota Katra \\
\hline $\begin{array}{l}\text { Administrative headquarters and residence of prince and } \\
\text { other imperial officers and soldiers }\end{array}$ & Old Afgan Fort, reconstructed during the Mughal period \\
\hline
\end{tabular}




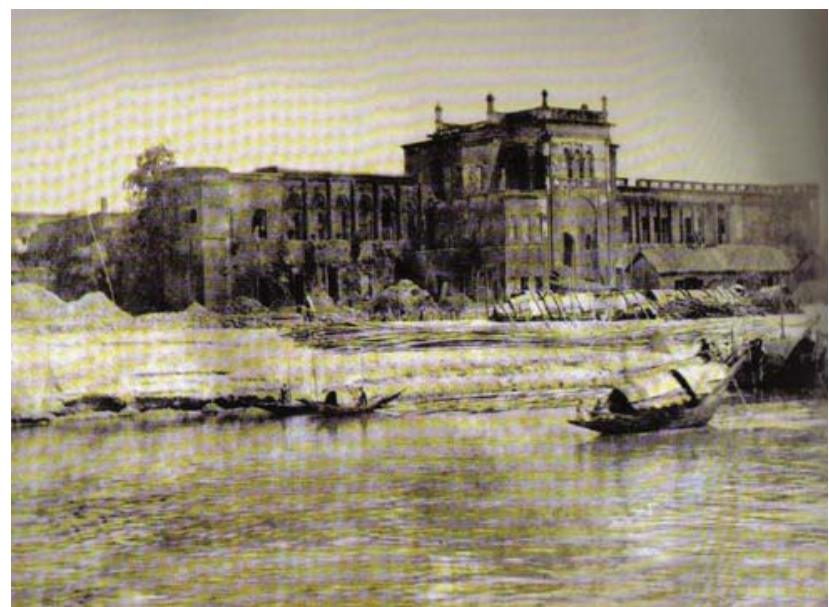

Figure-7: Chota Katra from the river bank in 1875 Source: Dept of Archeology, Bangladesh

\subsubsection{Zone-4 (Recreational zone)}

The Mughal elites had garden houses for recreation, festivity and reception. In the present Ramna area there were number of two or three storied mansions with spacious reception hall (see Table-5).

\subsection{British Settings (1765-1947)}

The new set up was laid mainly northward, round about Ramna racecourse area. Some roads within the old city were

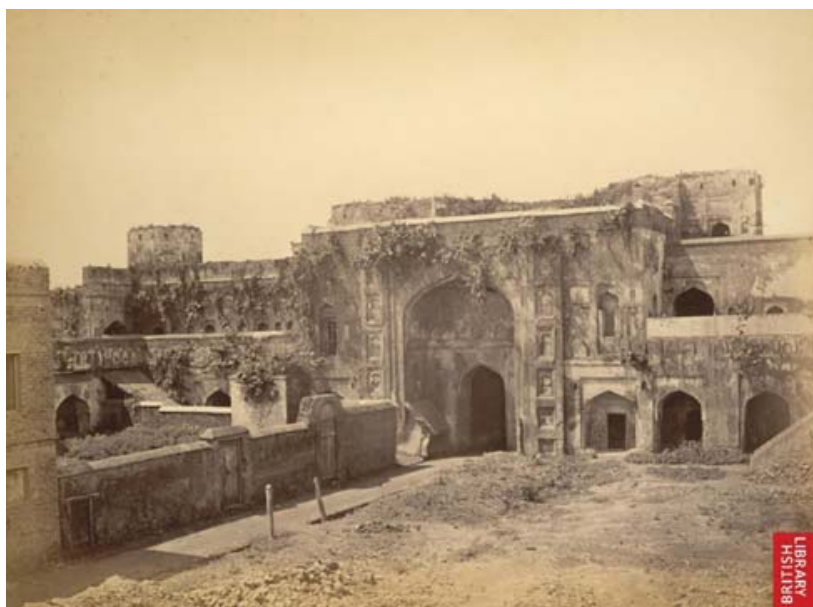

Figure-8: South wing from the court yard of Bara katra in 1870. Source: British museum

widened and new buildings were erected for administrative and educational purposes near the Victoria Park. The Old Fort was turned into jail. The localities of the Wari and Ganderia came into existence. Middle class residential areas were located mainly at Bakshi Bazar. Dewan Bazar, Nawab Katra, Aga Sadeq Road, Begum Bazar, Armanitola, Bangla Bazar and Lakshmi Bazar. The riverbank remained as highclass residential area. High European civil officers used to live there. (Figures-9, 10, $11 \&$ Table-6)

Table-5: Mughal Gardens

\begin{tabular}{|l|l|}
\hline \multicolumn{1}{|c|}{ USER GROUP } & \multicolumn{1}{c|}{ RECREATIONAL AREAS } \\
\hline Mughal elites & $\begin{array}{l}\text { Gardens at Hazari Bagh, Qazir Bagh, Lal Bagh, Bagh Chand Khan, Bagh Hosainuddin, } \\
\text { Bagh Musa Khan, Aram Bagh, Rajar Bagh, Mali Bagh and finally the Bagh-i-Badshahi } \\
\text { (Dani, 1962) }\end{array}$ \\
\hline
\end{tabular}

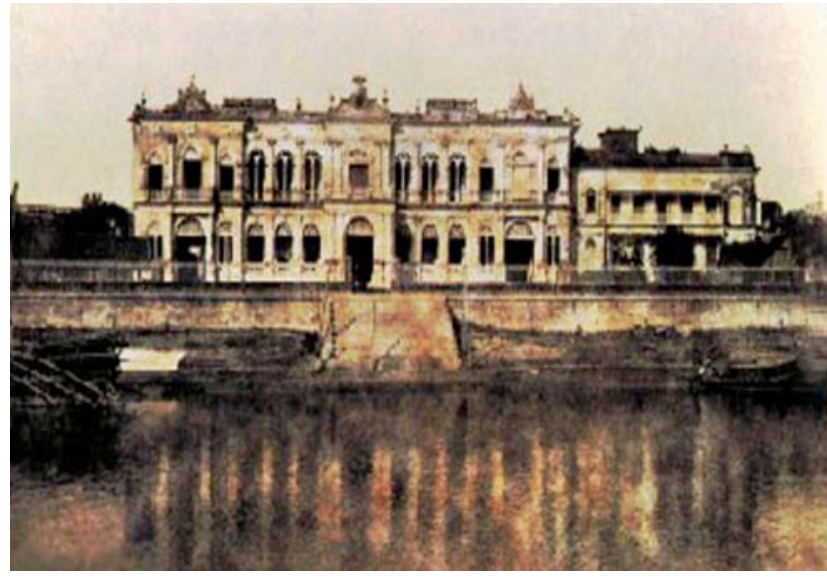

Figure-9: River side of Ruplal house in 19th century Source: Dept of Archeology, Bangladesh

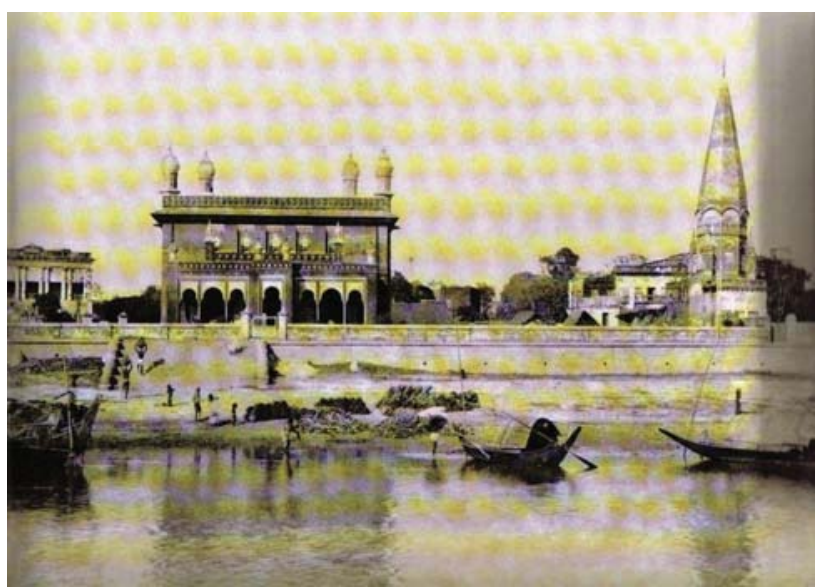

Figure-10: River side of North Brook hall in1904 Source: Dept of Archeology, Bangladesh 


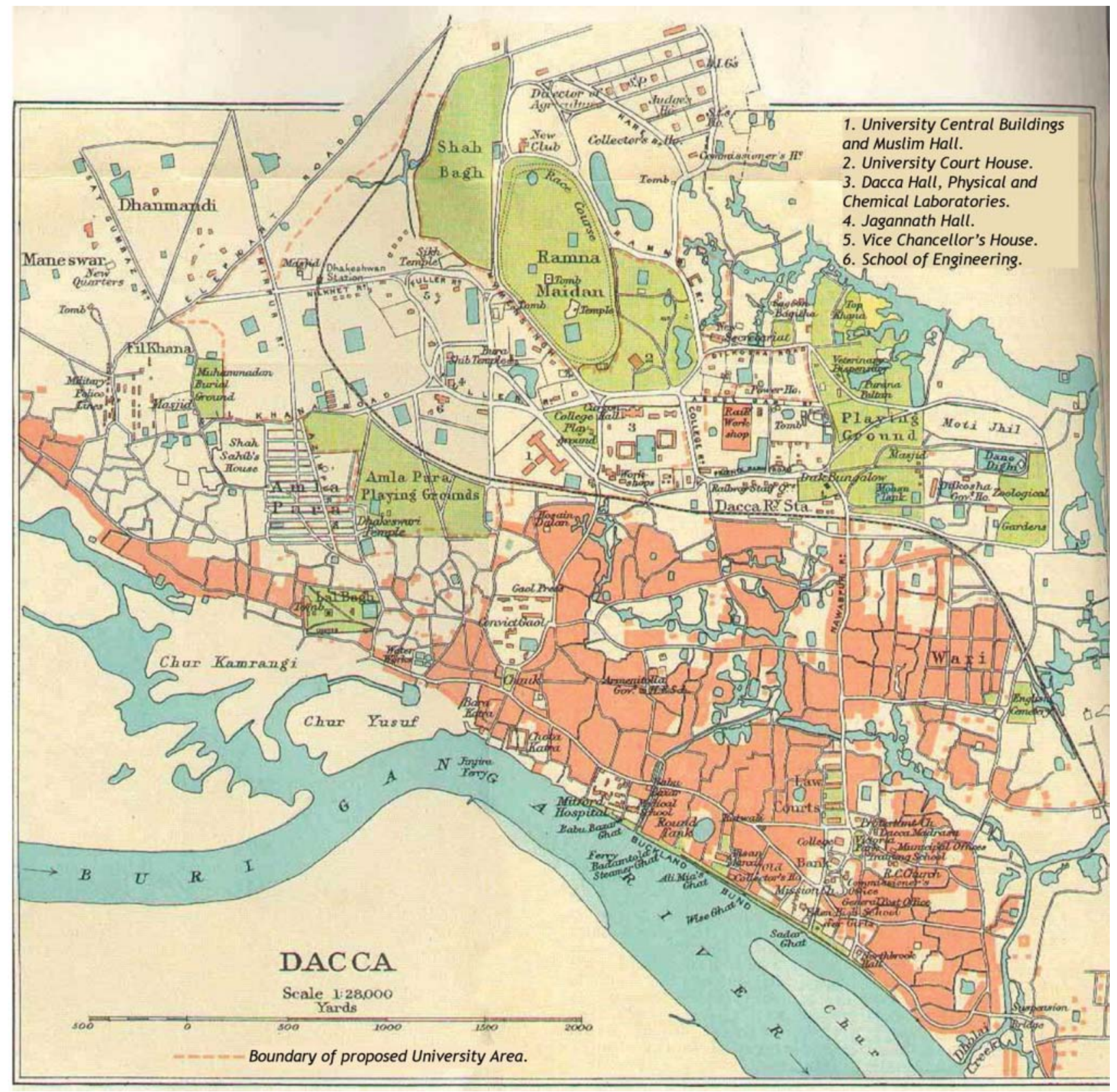

Figure-11: Dacca 1924

Source: http://en.wikipedia.org/wiki/History_of_Dhaka

Table-6: Building in British Period

\begin{tabular}{|l|l|}
\hline \multicolumn{1}{|c|}{ TYPES } & \multicolumn{1}{c|}{ BUILDINGS } \\
\hline Religious buildings & Armenian Church, Anglican Church \\
\hline Residential buildings & Ahsan Manjil, Ruplal House, etc \\
\hline Secular public buildings & North Brook Hall, Mitford Hospital etc \\
\hline
\end{tabular}




\section{POST COLONIAL (BRITISH) TRANSFORMATION (AFTER 1947)}

After the partition of British-India in 1947 Dhaka acted as the capital of the then East Pakistan. After the liberation in 1971, Dhaka became the capital of Bangladesh. Dhaka continued to expand farther to the north. The old city has gradually become congested due to unplanned growth. Since 1947, most part of the area has been loosing residential qualities and transforming rapidly to a wholesale \& retail area. Historic buildings have been subdivided for multiple uses and densities have risen to inordinate level due to encroachment and growth of informal settlements around. Cannels like Dholai khal and Begunbari khal that worked as important traffic conduit are filled up to create land for new settlements.

\section{EXISTING SITUATION}

The old city is currently considered as historic core and commercial nerve of Dhaka. The existing city web is very difficult to maintain as the organic growth has remained apparently unaffected by coerced geometry. But it is important from the perspective of urban conservation as many design qualities are inherent in such townscape. Many Government organizations play proactive role to safeguard the built heritage of the old city (see Table-7).

\subsection{Urban Pattern and Spatial Divisions}

The socio cultural dynamics resulted in the formation of spontaneous neighborhood, known as para, mahalla that act as the basic spatial unit to form the organic pattern in the urban web. Documentation of these informal units of urban web is necessary which should cover primary measurements including height, nature of internal divisions, use etc. Comprehensive strategy may be required to determine different level of interventions for different spatial divisions on the basis of their townscape value. (see Figures-12 \& 13).

The basic pattern evolved hierarchy of spaces; court, lanes, node, market place etc and manifested the socio-cultural quality of urban life that should be preserved. Landing platforms at river bank establish significant linkage between streets and river. The typical lanes and by lanes of old Dhaka are extremely narrow with curves that often create difficulties for the modern transport but offer changing views during pedestrian movement. The streets are typically accompanied by urban services. The street front should be considered as principal part for conservation as the continuous façade of old settlements represent strong urban character. The Buckland embankment, that once used to offer recreational facilities for quality urban life have undergone changes due to the growth of informal settlements.

Table-7: Major Actors for conservation of old Dhaka.

\begin{tabular}{|l|l|}
\hline \multicolumn{1}{|c|}{ ACTORS } & \multicolumn{1}{c|}{ ROLE } \\
\hline Department of Archaeology & $\begin{array}{l}\text { Dept of Archaeology is the main authority concerning the Conservation \& management } \\
\text { of the Historic sites. }\end{array}$ \\
\hline $\begin{array}{l}\text { RAJUK (Capital } \\
\text { Development Authority) }\end{array}$ & Control new developments on and around historic sites. \\
\hline Department tourism & Promote tourism \\
\hline Dhaka City Corporation & Provide municipal services \\
\hline
\end{tabular}
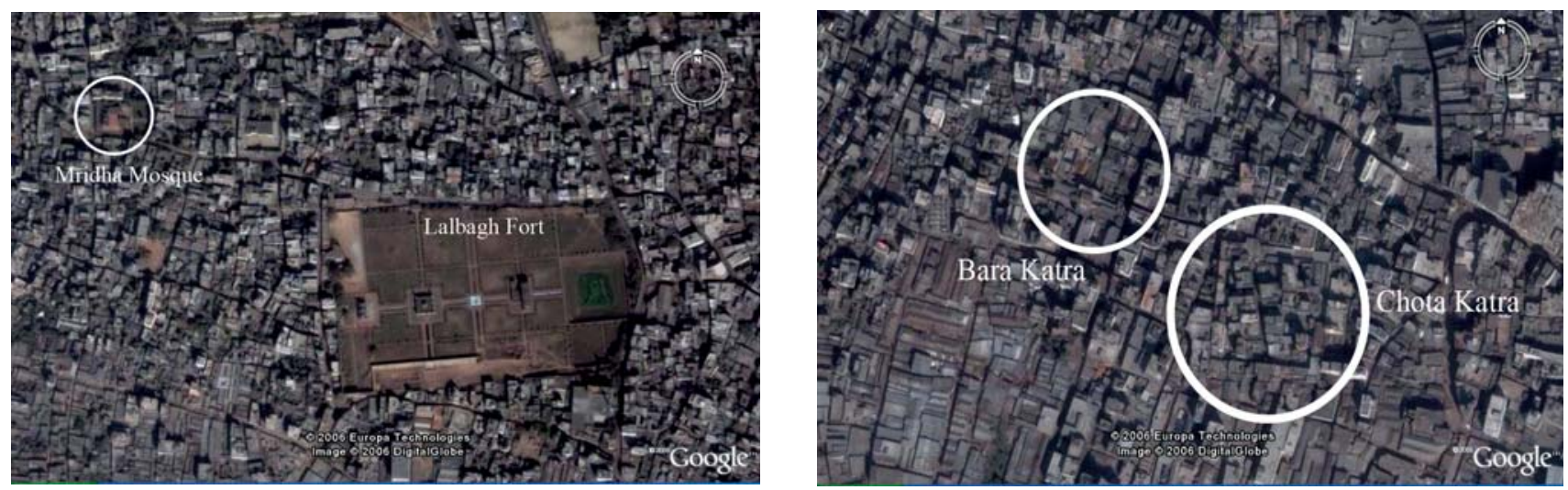

Figure-12 \& 13: Historic artifacts in the dense settlements.(Hossain, 2007a) 
Documentation and preservation of the streets should cover dimensions, width, sidewalk, changes in length, urban hierarchy, allocation of services, physical and qualitative characteristic of the intersections etc.

\subsection{Historic Buildings and Sites}

The historic settlements stand in great contrast to the new developments. Historic Building has almost become isolated element of the present fabric. Very few of these structures are preserved but most of them exist in deplorable condition and are gradually deteriorating due to lack of maintenance. There is a need to carry architectural documentation of these historic buildings. The historic structures are hidden within newly developed dense settlements that create visual obstacle and poor access to the historic buildings. The following survey was carried out on the existing conditions of some historic buildings in the present fabric: (Figures-14 to $21 \&$ Table-8)

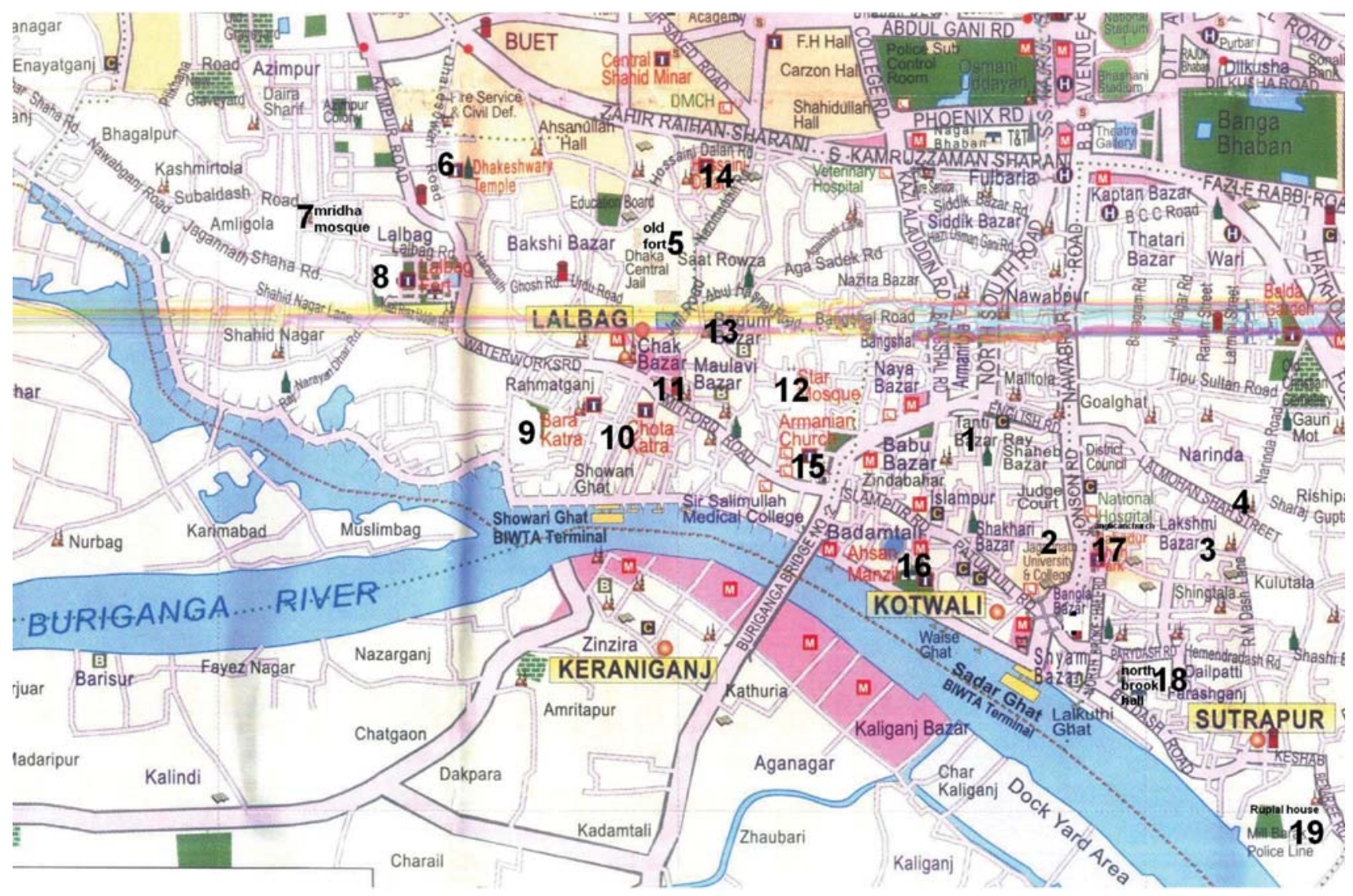

Figure-14: Historic monuments in old Dhaka

1. Tanti Bazaar

4. Binat Bibi Mosque

7. Khan Mohammad Mridha's Mosque

10. Chota Katra

13. Kartalab Khans Mosque

16. Ahsan Manjilm

19. Ruplal House
2. Shakhari Bazarr

5. Old Fort

8. Lal Bagh Fort

11. Chauk Bazaar Mosque

14. Hussaini Dalan

17. Anglican Church
3. Lakhsmi Bazaar

6. Dhakeshwari Temple

9. Bara Katra

12. Star Mosque

15. Armenian Church

18. Northbrook Hall 
Table-8: Existing condition of the Historic structures in the present fabric.

\begin{tabular}{|c|c|c|c|c|}
\hline \begin{tabular}{|l|} 
Historic \\
Structure
\end{tabular} & Legal Status & $\begin{array}{l}\text { Accessibility } \\
\text { \& visibility }\end{array}$ & Physical Condition & Present Use \\
\hline $\begin{array}{l}\text { Tanti } \\
\text { Bazaar }\end{array}$ & $\begin{array}{l}\text { Enlisted by } \\
\text { RAJUK. as } \\
\text { heritage site }\end{array}$ & Poor & $\begin{array}{l}\text { Extremely dilapidated } \\
\text { condition, }\end{array}$ & Shop house \\
\hline $\begin{array}{l}\text { Shakhari } \\
\text { Bazaar }\end{array}$ & $\begin{array}{l}\text { Enlisted by } \\
\text { RAJUK as } \\
\text { heritage site }\end{array}$ & Poor & $\begin{array}{l}\text { Extremely dilapidated } \\
\text { condition, }\end{array}$ & Shop house \\
\hline $\begin{array}{l}\text { Binat } \\
\text { Bibi Mosque }\end{array}$ & $\begin{array}{l}\text { Enlisted by } \\
\text { RAJUK as } \\
\text { heritage building }\end{array}$ & Poor & $\begin{array}{l}\text { Existing with extreme } \\
\text { alternations to the } \\
\text { original structure }\end{array}$ & $\begin{array}{l}\text { Original use as } \\
\text { Mosque }\end{array}$ \\
\hline $\begin{array}{l}\text { Dhakeshwari } \\
\text { Temple }\end{array}$ & $\begin{array}{l}\text { Enlisted by } \\
\text { RAJUK as } \\
\text { heritage building }\end{array}$ & Good & Requires proper maintenance & Original use \\
\hline Old Fort & $\begin{array}{l}\text { Not Enlisted as } \\
\text { heritage building }\end{array}$ & $\begin{array}{l}\text { Accessible but } \\
\text { not visible from } \\
\text { distant due to } \\
\text { newly built } \\
\text { surrounding } \\
\text { structures }\end{array}$ & $\begin{array}{l}\text { Existing with several } \\
\text { alternations to the } \\
\text { original structure. }\end{array}$ & Central Jail \\
\hline $\begin{array}{l}\text { Khan } \\
\text { Mohammad } \\
\text { Mridha's } \\
\text { Mosque }\end{array}$ & $\begin{array}{l}\text { Enlisted by RAJUK } \\
\text { as heritage building } \\
\& \text { Department of } \\
\text { Archaeology for } \\
\text { protection }\end{array}$ & $\begin{array}{l}\text { Accessible but } \\
\text { not visible from } \\
\text { distant due to } \\
\text { newly built } \\
\text { surrounding } \\
\text { structures }\end{array}$ & $\begin{array}{l}\text { Preserved and maintained } \\
\text { by Department of Archaeology }\end{array}$ & $\begin{array}{l}\text { Original use as } \\
\text { Mosque }\end{array}$ \\
\hline $\begin{array}{l}\text { Lal Bagh } \\
\text { Fort }\end{array}$ & $\begin{array}{l}\text { Enlisted by RAJUK } \\
\text { as heritage building } \\
\& \text { Department of } \\
\text { Archaeology for } \\
\text { protection }\end{array}$ & $\begin{array}{l}\text { Accessible but } \\
\text { not visible from } \\
\text { distant due to } \\
\text { newly built } \\
\text { surrounding }\end{array}$ & $\begin{array}{l}\text { Preserved and maintained by } \\
\text { Department of Archaeology } \\
\text { Some portion is still encroached }\end{array}$ & Museum \\
\hline Bara Katra & $\begin{array}{l}\text { Enlisted by RAJUK } \\
\text { as heritage building } \\
\& \text { Department of } \\
\text { Archaeology for } \\
\text { protection }\end{array}$ & $\begin{array}{l}\text { structures } \\
\text { Extremely Poor }\end{array}$ & $\begin{array}{l}\text { Extremely dilapidated condition, } \\
\text { inner court and surroundings } \\
\text { are extensively encroached }\end{array}$ & $\begin{array}{l}\text { Subdivided \& used } \\
\text { as Warehouse, School, } \\
\text { Residence, Shops etc. }\end{array}$ \\
\hline Chota Katra & $\begin{array}{l}\text { Enlisted by RAJUK } \\
\text { as heritage building } \\
\& \text { Department of } \\
\text { Archaeology for } \\
\text { protection }\end{array}$ & Extremely Poor & $\begin{array}{l}\text { Extremely dilapidated condition, } \\
\text { inner court and surroundings are } \\
\text { extensively encroached }\end{array}$ & $\begin{array}{l}\text { Subdivided \& used } \\
\text { as Warehouse, School, } \\
\text { Residence, Shops etc. }\end{array}$ \\
\hline
\end{tabular}

Continued... 


\begin{tabular}{|c|c|c|c|c|}
\hline \begin{tabular}{|l|} 
Historic \\
Structure
\end{tabular} & Legal Status & $\begin{array}{l}\text { Accessibility } \\
\text { \& visibility }\end{array}$ & Physical Condition & Present Use \\
\hline Star Mosque & $\begin{array}{l}\text { Enlisted by RAJUK } \\
\text { as heritage building }\end{array}$ & $\begin{array}{l}\text { Accessible but } \\
\text { not visible from } \\
\text { distant due to } \\
\text { newly built } \\
\text { surrounding } \\
\text { structures }\end{array}$ & $\begin{array}{l}\text { Existing with several alternations } \\
\text { to the original structure. } \\
\text { Requires proper preservation } \\
\text { and maintenance }\end{array}$ & $\begin{array}{l}\text { Original use as } \\
\text { Mosque }\end{array}$ \\
\hline $\begin{array}{l}\text { Kartalab } \\
\text { Khan's } \\
\text { Mosque }\end{array}$ & $\begin{array}{l}\text { Enlisted by RAJUK } \\
\text { as heritage building }\end{array}$ & $\begin{array}{l}\text { Accessible but } \\
\text { not visible from } \\
\text { distant due to } \\
\text { newly built } \\
\text { surrounding } \\
\text { structures }\end{array}$ & $\begin{array}{l}\text { Existing with alternations } \\
\text { to the original structure. } \\
\text { Requires proper preservation } \\
\text { and maintenance }\end{array}$ & $\begin{array}{l}\text { Original use as } \\
\text { Mosque }\end{array}$ \\
\hline $\begin{array}{l}\text { Hussaini } \\
\text { Dalan }\end{array}$ & $\begin{array}{l}\text { Enlisted by RAJUK } \\
\text { as heritage building }\end{array}$ & $\begin{array}{l}\text { Accessible and } \\
\text { partly visible } \\
\text { from distant }\end{array}$ & $\begin{array}{l}\text { Existing with alternation } \\
\text { to the original structure. } \\
\text { Requires proper preservation } \\
\text { and maintenance }\end{array}$ & Original use \\
\hline $\begin{array}{l}\text { Ahsan } \\
\text { Manjil }\end{array}$ & $\begin{array}{l}\text { Enlisted by RAJUK } \\
\text { as heritage building }\end{array}$ & Good & $\begin{array}{l}\text { Preserved and maintained } \\
\text { by national Museum }\end{array}$ & Museum \\
\hline $\begin{array}{l}\text { Armenian } \\
\text { Church }\end{array}$ & $\begin{array}{l}\text { Enlisted by RAJUK } \\
\text { as heritage building }\end{array}$ & $\begin{array}{l}\text { Accessible but } \\
\text { not visible from } \\
\text { distant due to } \\
\text { newly built } \\
\text { surrounding } \\
\text { structures }\end{array}$ & Requires proper maintenance & $\begin{array}{l}\text { Original use as } \\
\text { Church }\end{array}$ \\
\hline $\begin{array}{l}\text { Anglican } \\
\text { Church }\end{array}$ & $\begin{array}{l}\text { Enlisted by RAJUK } \\
\text { as heritage building }\end{array}$ & $\begin{array}{l}\text { Accessible but } \\
\text { not visible from } \\
\text { distant due to } \\
\text { newly built } \\
\text { surrounding } \\
\text { structures }\end{array}$ & Requires proper maintenance & $\begin{array}{l}\text { Original use as } \\
\text { Church }\end{array}$ \\
\hline $\begin{array}{l}\text { Northbrook } \\
\text { Hall }\end{array}$ & $\begin{array}{l}\text { Enlisted by RAJUK } \\
\text { as heritage building } \\
\& \text { Department of } \\
\text { Archaeology for } \\
\text { protection }\end{array}$ & $\begin{array}{l}\text { Accessible but } \\
\text { not visible from } \\
\text { the river side } \\
\text { due to newly } \\
\text { built structures }\end{array}$ & Requires proper maintenance & $\begin{array}{l}\text { Library \& town } \\
\text { Hall }\end{array}$ \\
\hline $\begin{array}{l}\text { Ruplal } \\
\text { House }\end{array}$ & $\begin{array}{l}\text { Enlisted by RAJUK } \\
\text { as heritage building } \\
\& \text { Department of } \\
\text { Archaeology for } \\
\text { protection }\end{array}$ & Poor & Dilapidated condition & $\begin{array}{l}\text { Subdivided as } \\
\text { Warehouse \& } \\
\text { Whole Sale Market }\end{array}$ \\
\hline
\end{tabular}




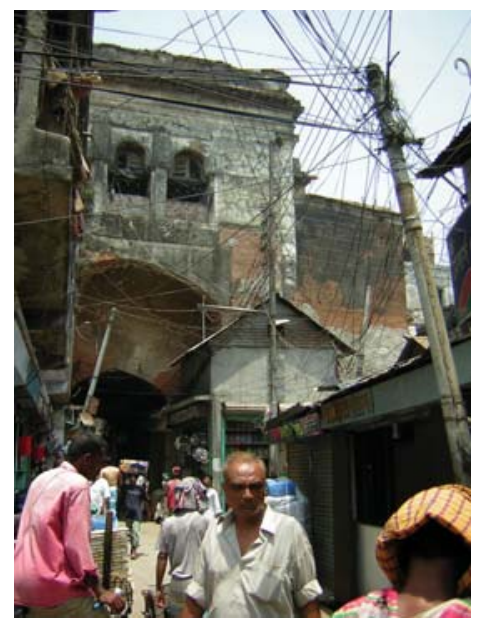

Figure-15: Approach road to Choto Katra (Hossain, 2007b)

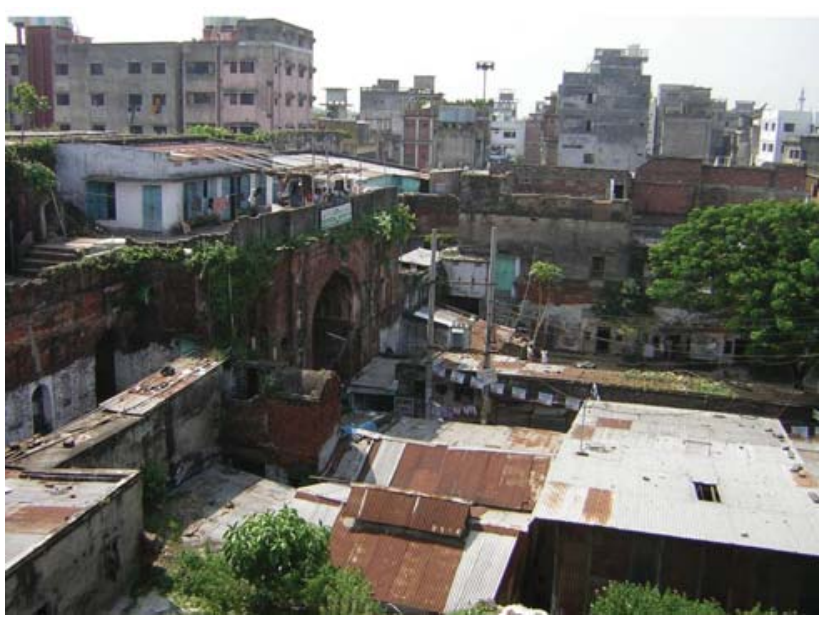

Figure-16: Courtyard \& the southern wing of Bara Katra (Hossain, 2006)

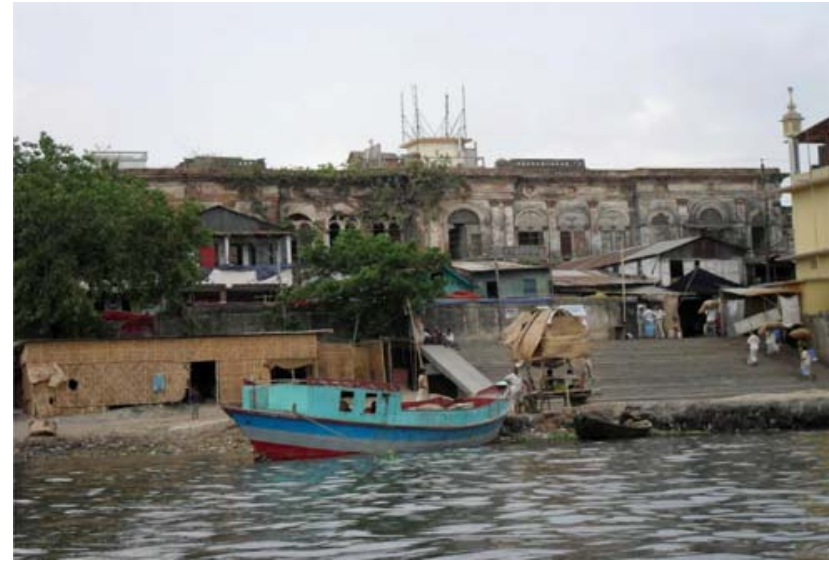

Figure-17: Existing River side of Ruplal house.

Source: http://icwow.blogspot.com/2010/04/dhaka-ruplal-house.html

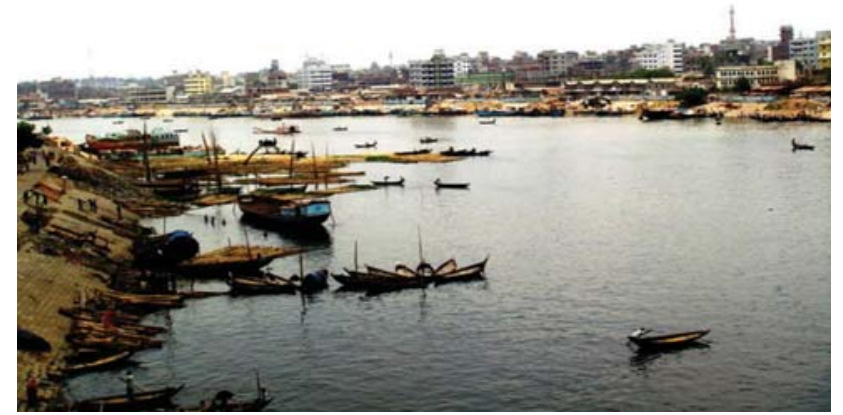

Figure-18: Existing River side of Chawkbazar \& Lalbagh area. Source: http://dhakadailyphoto.blogspot.com/2007_05_01_archive.html

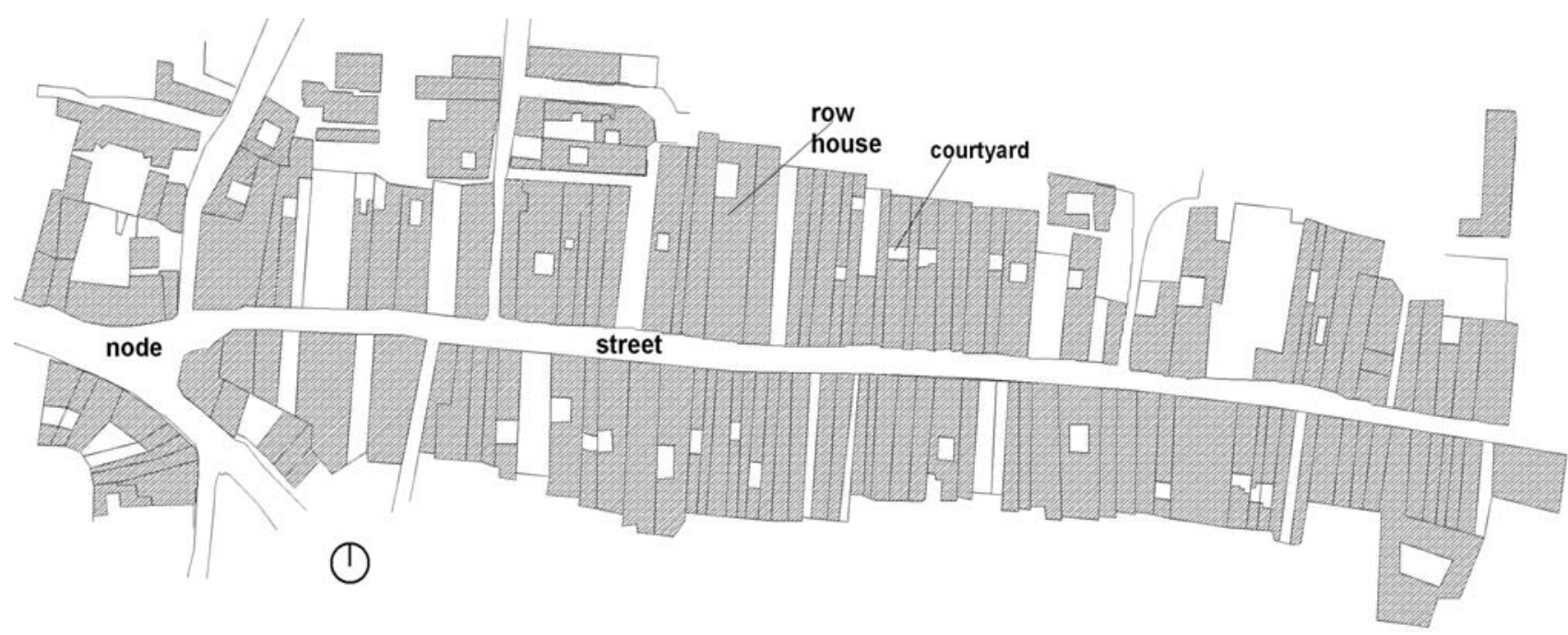

Figure-19: Layout of row houses at Shankhari Bazaar in 2006. Source: Ahmed, 2012. 

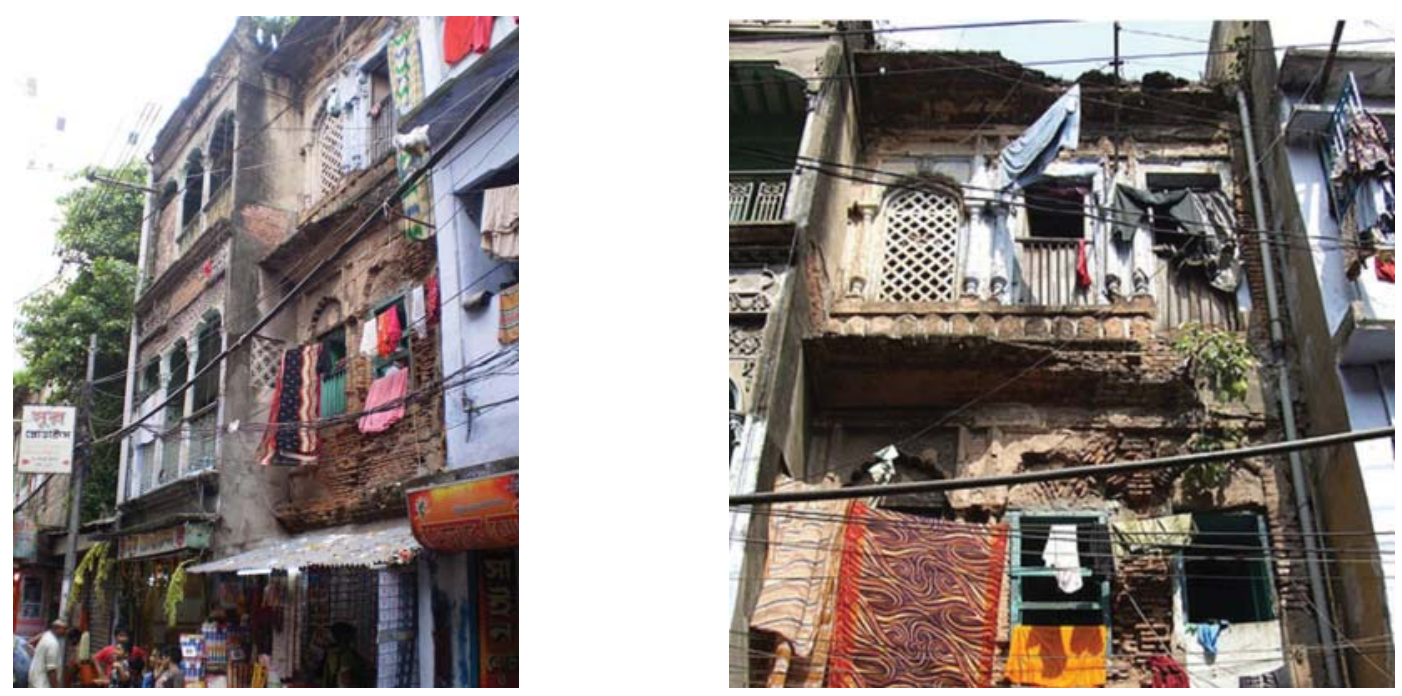

Figure-20 \& 21: Existing condition of the row houses at Shankhari Bazaar (Bahauddin, 2010)

\section{PLANNING CONSERVATION}

Urban planning and conservation may act as semiotics (Cohen, 1999). Shifting focus from individual buildings to urban context during conservation may reinforce the urban pattern to incorporate the new structures into the old fabric. Conservation therefore may be judged as a planning concept and tool to justify the urban form to incorporate the new and the old to maintain the urban continuity. Urban conservation can be correctly conceived within the frame of a general approach to urban problem. Basic methodology of urban conservation can be compared with classical town planning that considers the past along with future as fundamental element of planning (Lemaire, 1996). To a large degree historic city manifest characteristics of self preservation. It is important to establish guidelines as to the nature of intervention to meet the standards of historic value and adopt those in response to the economic and social realities in which the building is to be used.

\subsection{Special Planning Zone}

The entire old city may be considered as a special planning zone to protect the scale, visual exposure, skyline and different qualities of the old urban fabric. "Dhaka Metropolitan Building Construction, Development, Protection and Removal Rule-2008" already introduced constructionrestriction within the encircling area of 250 meters radius around historic structures. This rule still needs to give specific guidelines for color, texture, material, façade design, height, function, set back, orientation and other design specification for any new structures in the existing fabric. So the identical new structures may ensure authenticity and integrity of the urban structures. Moreover, an effective buffer zone should be introduced to protect the old structures from traffic vibration, noise pollution, air pollution, water pollution and other threats.

\subsection{Traffic Restriction}

Narrow and curved street, irregular crossing, and shortage of parking spaces in the old city are not suitable for modern mechanical traffic system as the old pattern can provide efficient living condition when based on pedestrian circulation or slow moving vehicles. Traffic vibration is a major constraint to manage damage and decay of the old fabric. Moreover unrestricted access of slow and fast moving vehicles results in protracted congestion. There is a need to introduce strong control over mechanical traffic in the area. Parking may be considered on the perimeter outside a ring road with loops into the centre. The center may be restricted to pedestrian movements, light vehicles and limited number of heavy vehicles. Shifting focus more to water transportation may also reduce traffic load on the existing roads.

\subsection{Access, Exposure and Buffer}

Many historic buildings in old Dhaka had substantial open spaces like gardens and courts that are now mostly encroached by newly built informal settlements. These informal settlements are creating obstacle for access and visual exposure to the historic artifacts. Some of such open spaces were recovered during the conservation of Lal Bagh fort, 
Khan Mohammad Mridha Mosque and Ahsan Manjil. It is important to recover such open spaces at other historic buildings like Bara Katra and Choto Katra, Ruplal house, etc to ensure proper access and visual exposure as well as substantial buffer to the historic buildings. View corridors may be also created through the fabric to get distant and interesting view of the urban elements. Some of the historic buildings have already lost their original approach from the riverside and inner city due to newly imposed settlements in the fabric. So, small routes for heritage walk may be developed within the present fabric to ensure interesting approach and promote cultural tourism. (see Figures-22, 23)

\subsection{Preserving the Street Elevation and River Front}

The historic structures at the bank of the river used to produce magnificent view of the city. The river front and the street elevations of the old city need to be recovered to reveal the historic identity and integrity. The facades of the historic buildings should be preserved and restored to maintain the continuity of the riverside and street elevation of the old city.

\subsection{Relocation \& adaptive reuse}

To reduce densities, relocation of informal shelters and commercial establishments may be considered outside the old city. Many historic buildings are presently used as ware houses and whole sale area. These historic buildings should adopt sustainable uses like hotel, restaurant, souvenir shops, art galleries, craft shops and other enterprises that support tourism. Relocation of Central Jail may open up huge possibilities for the area to reduce emerging pressure on the old fabric. (see Figures-24 \& 25)

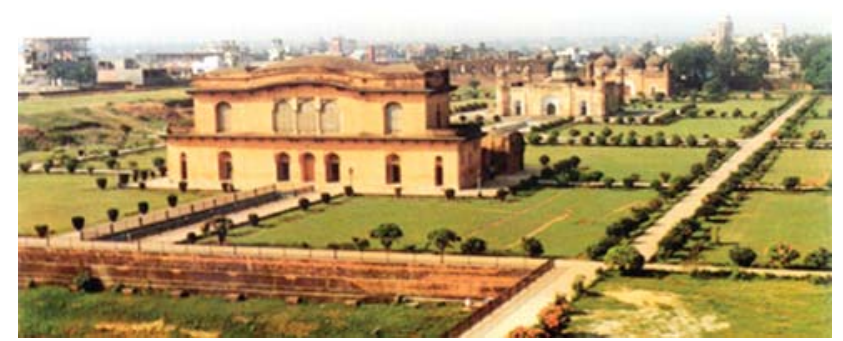

Figure-22: Lal Bagh fort complex after conservation (http://www.bpedia.org/T_0200.php)

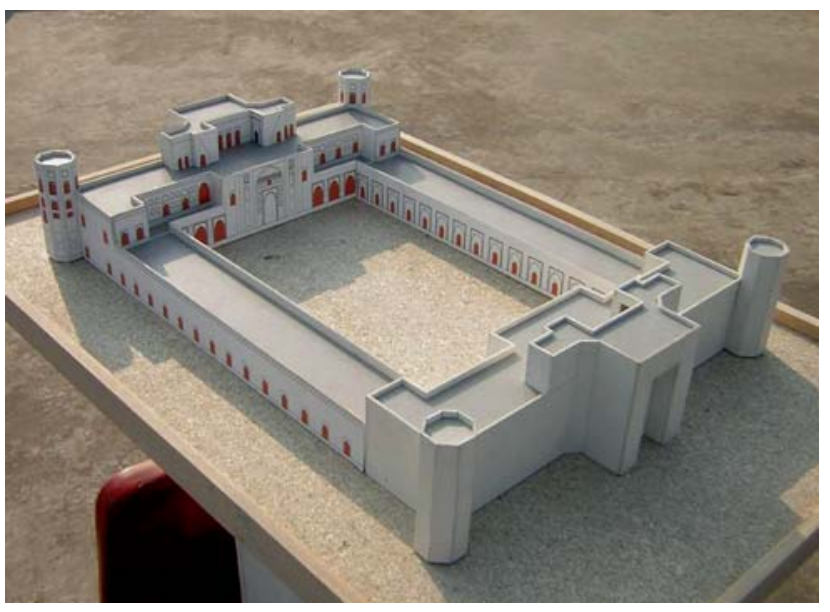

Figure-23: Barakatra with enclosed courtyard (Hossain, 2008)

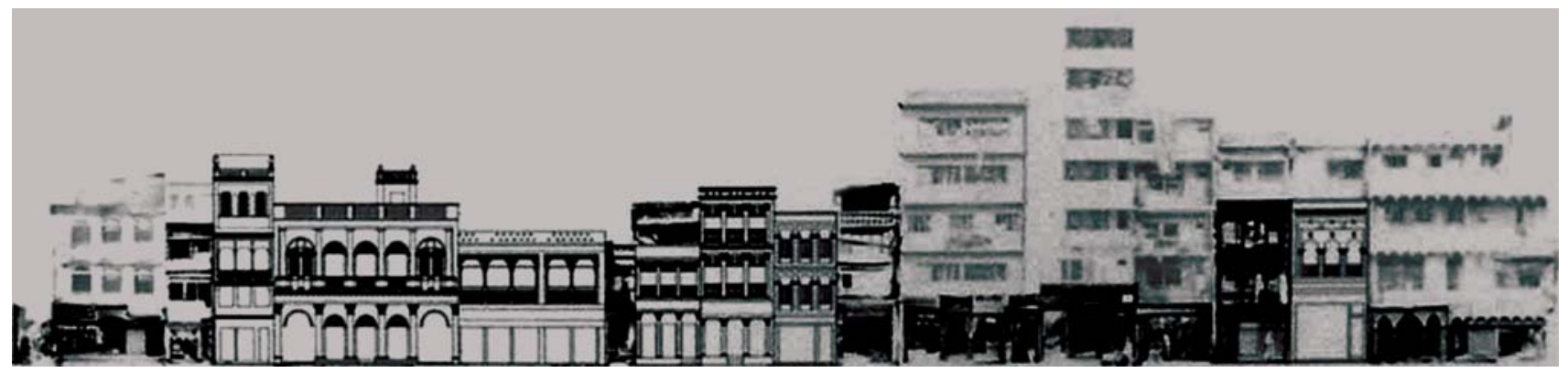

Figure-24: Street elevation of Shankari Bazaar Source: Urban study group 


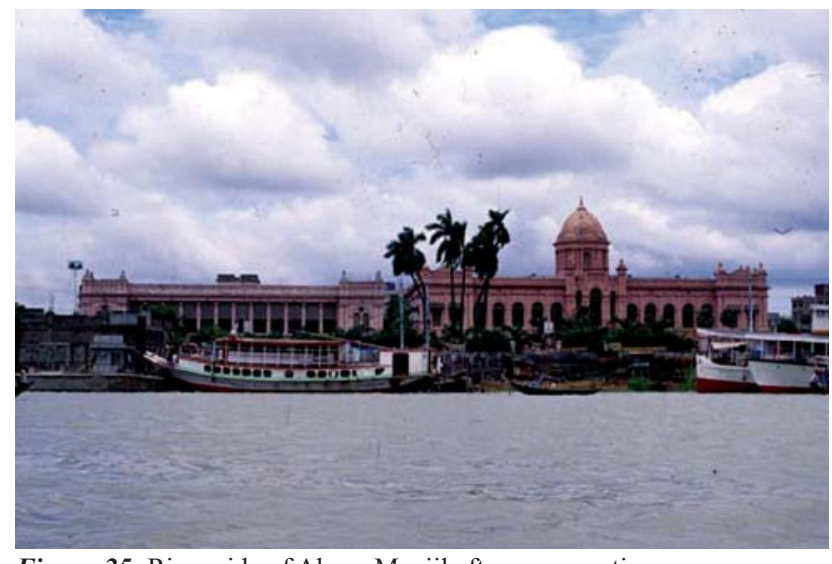

Figure-25: River side of Ahsan Manjil after conservation http://www.cemsonline.com/countryprofilebd.html

\section{CONCLUSION}

Old structures exist as witness of continuity of urban culture. Urban conservation is more than merely preserving few historic buildings and requires comprehensive approach to integrate important urban elements of the past within the existing urban tissues. Considering the townscape value for the heritage buildings the concept of integrated urban conservation was promoted by the ICOMOS, 'Charter for the Conservation of Historic Towns and Urban Areas' in 1987. Under the light of this Charter the paper suggested some strategic guidelines for Old Dhaka. To understand the heterogeneous tissue the transformations of the city are carefully studied initially. Preventive strategies are mainly emphasized as intermediate guideline to manage decay and damages of the old fabric. Substantial buffer, proper set back, construction restriction and traffic restrictions may not only reduce the possibility of physical deterioration but also ensure proper access and visual exposures. To strengthen the state of authenticity and integrity at urban level, preservation of building envelops are highlighted to maintain street elevation and river side elevations. To avoid rigidity in architectural conservation different degree of interventions may be synthesized for different monuments. So it is not necessary to conserve the historic buildings in the conventional manner. Moreover Integration of historic monuments within the present urban fabric through development of contextual circulation pattern can promote interrelation among the monuments. During urban conservation it is important to manage the urban dynamics to control increasing pressure on establishment functions that causes rapid transformation. So policy and plans should be formulated to focus on adaptive reuse for the monuments to safeguard the historical patrimony. The city must continue to renew itself and it is not necessary to enact special legislation to preserve the original urban plan or to restrict the urban continuity in a static frame of any specific period. Urban conservation is necessary to relate past interventions and manage the urban dynamics to control increasing pressure that causes rapid transformation in the fabric. Thus conservation at urban level should be carried out as a continuous process and to maintain the transformation in sustainable manner.

\section{References}

Ahmed, I. (2012): “A Study of Architectural Heritage Management by Informal Community bodies in Traditional Neighborhoods of Old Fort Dhaka" - Unpublished Phd Thesis National University of Singapore.

Ahmed, S. U. (1986). “Dacca: A Study in Urban History and Development”. Dhaka: Curzon,Press.1986.

Bahauddin, M. (2010). “Conservation of Shakhari Bazar”, Unpublished training Report submitted at Lund University Sweden.

Cohen, N. (1999). “Urban Conservation”, MIT Press, Cambridge.

Dani, A. H. (1962). "Dacca-A Record of Its Changing Fortune”, Asiatic Society, Dhaka

Dani, A. H. (1956). “Dacca: A Record of it’s Changing Fortune”. Asiatic Press. Dhaka.

Denzin, N. K. and Lincoln, Y. S. (eds) (2000). "Handbook of Qualitative Research": SecondEdition. Thousand Oaks, CA: Sage.

DMDP- (1995-2015). "Dhaka Metropolitan Development Plan”, Volume I and 11.

Gupta, N. (1989). "Urbanization in South Asia in the Colonial Centuries" IN Sharif Uddin Ahmed (eds), Dhaka Past Present Future. The Asiatic Society of Bangladesh, Dhaka: 1989. 595-605. 
Islam, N. ( .1996a). "Megacity Management in the Asian and Pacific Region" IN Giles Clarke and Jeffry R. Stubbs (eds). Vol. 2, Megacity Management in the Asian and Pacific Region.ADB.

Islam, N. (.1996b ). "Dhaka from City to Mega City: Perspective on People, Places, Planning and Development Issues: Urban Studies Programme”, Department of Geography, University of Dhaka, Reprint.

Lemaire, R. (1996). "Why do we preserve historic towns?" - presented in the International Workshop on Architecture and Urban Conservation (December 1994) \& published in 1996, Centre for Built Environment, Calcutta.

Landman, W. A. (1988 ). "Navorsingsmetodologiese grondbegrippe/ Basic concepts in research methodology". Pretoria: Serva.

Nilufar, F. (2011). "Urban Morphology of Dhaka City: Spatial Dynamics of Growing City and the Urban Core" an Article published in 400 Years of Capital Dhaka and Beyond, Volume- III, Urbanization and Urban Development, Published by: Asiatic Society of Bangladesh, Dhaka ,pages 187-210.

Sazzad, H. M. (2006). "Conservation and Management of Bara Katra”, Unpublished training Report submitted at Lund University Sweden.

Sazzad, H. M. (2007a). "Planning the Heritage Cities- a case for Dhaka." Published in the Society Architects and Emerging Issues, published by Commonwealth Association of Architects (CAA) \& Institute of Architects of Bangladesh (IAB).

Sazzad, H. M. (2007b). "Revitalizing the Mughal Settlements in Old Dhaka", Published in Protibesh, Journal of the Departmetn of Architecture, BUET, Dhaka, Vol 11 (2), pp. 49 -54.

Sazzad, H. M. (2008). "Preventive Maintenance Strategy of Bara Katra" in Protibesh, Journal of the Departmetn of Architecture, BUET, Dhaka. July 2008, Vol 12 (2), pp. 5 -14

Taifoor, S. M. (1956). “Glimpses of Old Dhaka”. Pioneer. Dhaka. 